\title{
OB JUBILEJU DR. ANE KRAJNC
}

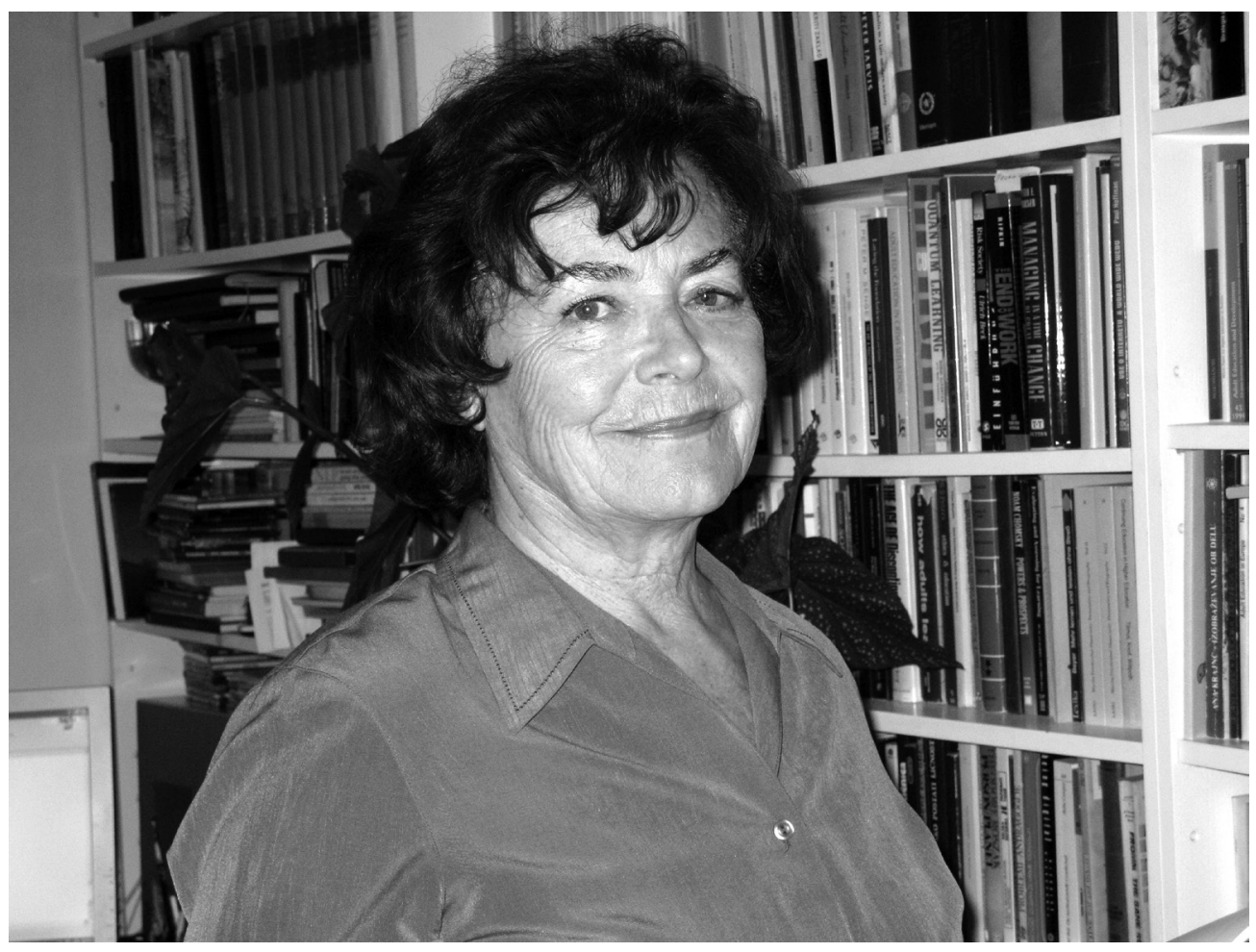

V letošnjem letu je ustanoviteljica in dolgoletna glavna urednica revije Andragoška spoznanja prof. dr. Ana Krajnc praznovala. Ker sama želi, da so praznovanja delovno obarvana, je bila to priložnost, da kolegi in kolegice pripravimo razmislek o raziskovanju na področju izobraževanja in učenja odraslih. Nastali sta dve publikaciji: znanstvena monografija Sodobne paradigme raziskovanja izobraževanja in učenja odraslih (ur. Ličen in Mezgec) in Človek mora biti dovolj drzen, da zagovarja svoje vrednote - Liber amicorum (ur. Ličen, Findeisen in Šantej). Slednja je izšla v sodelovanju med Slovensko univerzo za tretje življenjsko obdobje in Oddelkom za pedagogiko in andragogiko Filozofske fakultete, saj sta to dve delovni okolji dr. Ane Krajnc, ki ju je s svojimi inovacijami prepoznavno oblikovala. Naslov druge publikacije je citat iz intervjuja z Ano Krajnc »Človek mora biti dovolj drzen, da zagovarja svoje vrednote«, ki odseva njeno prepričanje, da je treba vztrajati pri tem, da z izobraževanjem spreminjamo življenje na bolje. V publikaciji so zbrane pripovedi različnih ljudi, ki so sodelovali z Ano Krajnc, in odsevajo mnogo trenutkov in 
občutij, kako so doživeli njeno delo. Nekatere pripovedi so globoko osebne, druge poudarijo njeno raziskovalno delo ter prodornost $\mathrm{v}$ spreminjanju strokovnega in raziskovalnega področja.

Monografija Sodobne paradigme raziskovanja izobraževanja in učenja odraslih ponuja mozaično ogledalo raziskovanja s področja andragogike, kakor se je razvilo v slovenskem prostoru iz »šole dr. Ane Krajnc«, kot smo gibanje poimenovali, ko smo poleti 2017 začeli pripravljati zbornik. Prva raziskovalka na področju izobraževanja odraslih je bila dr. Ana Krajnc, njeni doktorandi so raziskovalno delo nadaljevali, v sodobnosti pa se razvija široka mreža raziskovalcev in raziskovalk, ki združujejo vedenja mnogih disciplin.

V zborniku so zbrana besedila, ki uporabljajo različno epistemologijo, avtorji so različno stari in izkušeni. Uvodna poglavja prinašajo razmislek o sodobnih vprašanjih profesionalne identitete (dr. Tanja Možina) in obsežnih raziskavah pismenosti (dr. Petra Javrh). Raziskava PIAAC zadeva tematiko, ki ji je tudi dr. Ana Krajnc posvetila precej pozornosti, to je funkcionalna pismenost. Prispevek nakazuje, kako daleč smo v Sloveniji prišli $\mathrm{z}$ raziskovanjem funkcionalne pismenosti: od pilotne raziskave na nacionalni ravni do vključevanja v obsežne mednarodne raziskave OECD. Dr. Petra Javrh predstavlja refleksijo o nedavno zaključeni mednarodni raziskavi o spretnostih odraslih PIAAC in pomenu rezultatov, ki jih je dosegla Slovenija. Odgovore na tovrstne izzive, rezultati za Slovenijo namreč niso dobri, je treba iskati na sistemski ravni, ravno tako pa je na sistemski ravni treba določiti vlogo izobraževalcev odraslih in sistema izobraževanja odraslih. Nacionalne ureditve in sisteme vodijo smernice Evropske unije, kar velja tudi za področje izobraževanja odraslih. Prispevek dr. Dejana Hozjana proučuje sistemsko ureditev izobraževanja odraslih na evropski ravni ter trende vključevanja odraslih v izobraževanje med državami članicami. Izhajajoč iz strateških dokumentov in ukrepov, ki so namenjeni dvigovanju stopnje vključenosti prebivalstva v izobraževanje, ugotavlja, da prihaja do nehomogene porazdelitve participacije in posledično Evrope »dveh hitrosti«. Na ključne evropske dokumente s področja izobraževanja se sklicuje tudi dr. Marko Radovan, ki v svojem prispevku obravnava kompetenco »učenje učenja«, ki jo tudi Evropska komisija prišteva med ključne kompetence za uspešno spoprijemanje z izzivi 21. stoletja. Avtor kompetenco »učenje učenja« postavlja v središče razumevanja in spodbujanja učenja odraslih.

Pri proučevanju izobraževanja v družbi znanja ne moremo mimo raziskovanja kompetenc, razvoja kompetenc v kontekstu kariernega razvoja posameznikov. Digitalni svet postavlja vse višje zahteve in izzive za vseživljenjski razvoj kompetenc. Dr. Danijela Brečko poskuša v svojem prispevku ugotoviti, katere so glavne spremembe, ki spreminjajo zemljevide kompetenc, ter katere kompetence potrebujejo ljudje po t. i. četrti industrijski revoluciji. Dohitevanje sprememb je velik izziv za vse, za določene ciljne skupine pa je dohitevanje sprememb in stalno strokovno izobraževanje nuja. Med te ciljne skupine gotovo prištevamo strokovne delavce v vzgoji in izobraževanju. Posebno pozornost gre nameniti njihovemu nadaljnjemu izobraževanju in profesionalnemu razvoju. Prispevek dr. Jurke Lepičnik Vodopivec obravnava ciljno skupino vzgojiteljev predšolskih otrok, medtem ko prispevek dr. Danijele Makovec Radovan obravnava ciljno skupino učiteljev. 
Od tem, ki obravnavajo vseživljenjsko učenje in razvoj kompetenc ter profesionalni razvoj, se v monografiji postopoma pomaknemo k temam, ki obravnavajo izobraževanje za kariero v različnih kariernih obdobjih (dr. Miha Lovšin in dr. Nina Krmac). V perspektivi vseživljenjskega izobraževanja opravljajo pomembno vlogo tudi mentorji v izobraževanju odraslih (dr. Anita Jug Došler) in skupnostno izobraževanje, ki se uresničuje v obliki študijskih krožkov (dr. Nevenka Bogataj).

V družboslovju in humanistiki se je v sodobnosti uveljavila tudi interpretacijska paradigma raziskovanja, ki jo uporablja tudi andragogika za soočanje s problematikami, kot so migracije in večkulturna družba. $\mathrm{V}$ treh prispevkih o tej temi so v ospredju medgeneracijska transmisija kulture in identitete (dr. Maja Mezgec), migracije in učenje v odraslosti (dr. Klara Kožar Rosulnik) ter religijsko izobraževanje in intereligiozni dialog (dr. Tadej Stegu). V oporo novim področjem proučevanja andragoških tem velja omeniti etnografski pristop, ki ga oriše dr. Nives Ličen. Poleg prednosti nakaže tudi ambivalence, ki se pojavljajo pri uporabi etnografije in tudi širše pri uporabi kvalitativnih paradigem raziskovanja. Da je izobraževanje odraslih danes doseglo večrazsežnostni razvoj, izpričujejo tudi prispevki o temah, kot so skotopični sindrom (dr. Polona Kelava), družinska pismenost (dr. Livia Knaflič), učenje psihosocialnih veščin ob pojavu nasilja v partnerskem odnosu (dr. Jernej Kovač).

Zadnji prispevki v monografiji zajemajo teme, katerim dr. Ana Krajnc namenja veliko energije $\mathrm{v}$ svojem aktualnem delu, posebno pri prenosu teoretičnih spoznaj v prakso in uvajanju inovativnih rešitev in oblik, to je izobraževanje starejših. Prispevki se dotikajo aktualnih tem. To so: izobraževanje starejših voznikov (mag. Andrej Justinek), stereotipi o starejših (dr. Anita Zovko in mag. Ivana Damjanič), kakovost življenja v tretjem življenjskem obdobju (mag. Dajana Kuzma, dr. Anita Zovko in dr. Sofija Vrcelj), pomen mednarodnih projektov za učenje starejših (Meta Furlan) in mentorstvo za starejše (dr. Monika Govekar-Okoliš in dr. Renata Kranjčec).

Publikaciji - vsaka v svojem slogu - kažeta pomembnost učenja in izobraževanja odraslih ter pomembnost dela dr. Ane Krajnc na mnogih področjih, ki jih je kot inovatorka postavljala v slovenskem in evropskem prostoru, saj je bila dejavna v mednarodnih združenjih (npr. International Council for Adult Education ICAE, UNESCO, uredniški odbori različnih revij, Andragoško društvo Jugoslavije). V sodobnosti razvija področje izobraževanja starejših, ozavešča o pomenu poznavanja disleksije in skotopičnega sindroma, zavzema se za pravico do izobraževanja za vse skupine ljudi in za prepoznavanje raznolikosti učenja.

Uredniški odbor revije Andragoška spoznanja profesorici čestita za vse dosežke.

Ponosni smo, da lahko njeno delo nadaljujemo. 